\title{
Serological Study of Human Cytomegalovirus in Thalassemia Patients and Blood Donors and its Relation to IL-6 in Kirkuk City
}

\author{
Neshtiman A. Abbas \\ Najat A. Zaman \\ Department of Biology/ College of Science / University of Kirkuk
}

\section{E-mail: $\underline{\text { Ada71566@yahoo.com }}$}

\section{(Received 4/9/2018; Accepted 3/12/2018)}

\begin{abstract}
The aim of this study was to determine the relationship of human cytomegalovirus in thalassemic patients and blood donors in relation to IL-6 in Kirkuk City through screening of antihuman cytomegalovirus IgM and IgG antibodies in the serum of thalassemic patients and blood donors by using ELISA technique to detect the IgG and IgM in blood samples. Blood samples were collected from 200 thalassemic patients and 180 samples from blood donor. The study revealed that the positive rates for HCMV-IgG, HCMV-IgM and both HCMV IgM/IgG were positive among 152(76.0\%),14,(7.0\%) and 3(1.5\%) respectively. The rates of HCMV antibodies among 180 blood donors HCMV-IgG was detected in $68(37.77 \%)$, the seropositive for HCMV-IgM was $7(3.88 \%)$, while for both HCMV-IgG and HCMV-IgM was 4(2.22\%). The HCMV elaborate cellular and immune manipulation strategies to maintain the virus-host equilibrium and the human immune response by humeral and cellular immunity including some cytokines as IL-6, so the rates of increased serum IL-6 was high among most HCMV seropositive subjects enrolled in this study although the highest rate were within thalassemic patients.
\end{abstract}

Keywords: HCMV, Thalassemia patients, Blood donors, ELISA, IL-6.

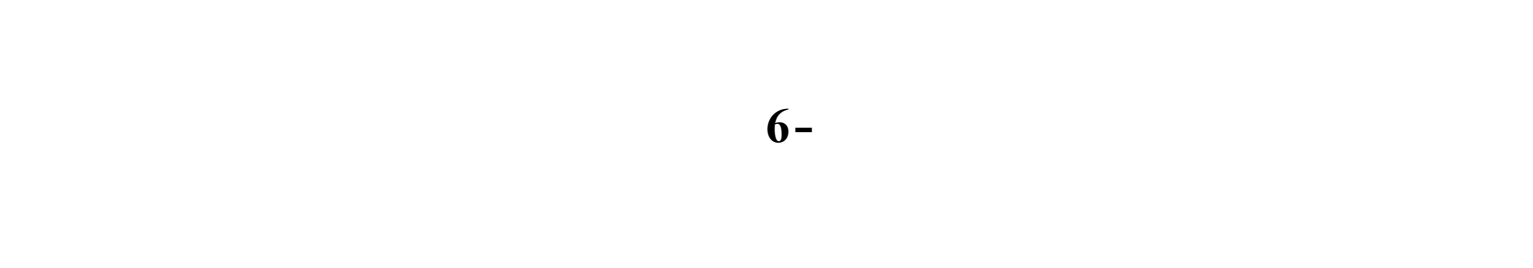

الهدف من هذه الدرلسة هو تحديد العلاقة بين الفيروس المضهم للخلايا البثري Human cytomegalovirus عند

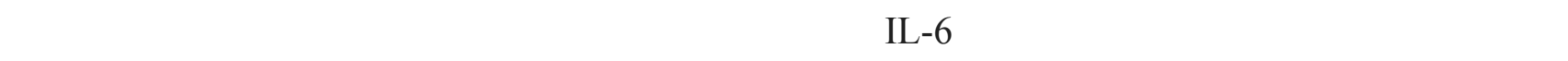

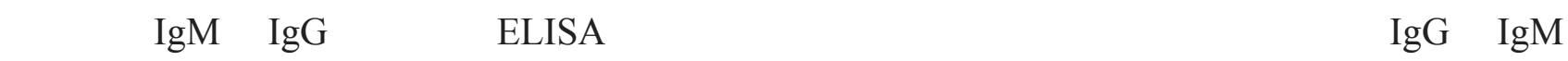
الهم. عينات الدم التي م جمعها من 200 من مرض الثلمسيميا و 180 عينة من المتبرعين بالدم. كثفت الدرلسة أن النتيجة

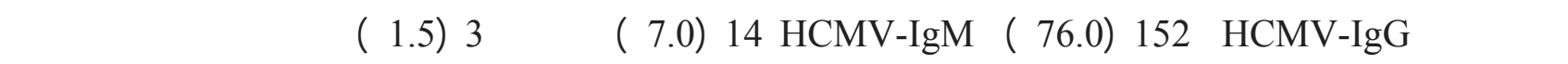
HCMV IgM / IgG 68 (37.77٪) من عدد 180 من متبرعي الدم، وكانت نتيجة الفحص موجبة بخصوص الأجسلم المضادة المصل الإيجابي لـ ـ

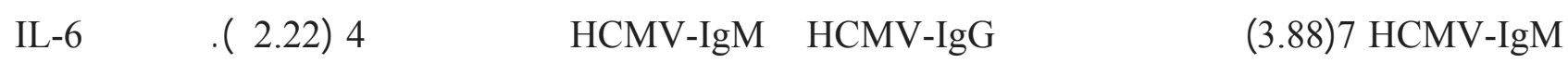
لحد للسايتوكينات المهمة في المناعة الخطية والخلوية للمحلظة على التوازن في الاستجابة المناعية الخاصة تجه الفيروس،

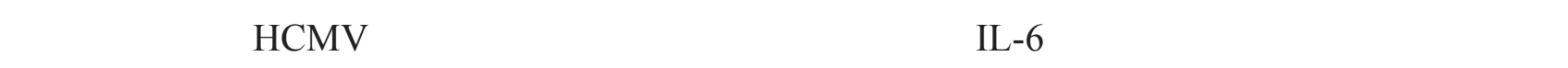

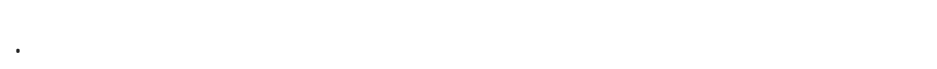

الهاملت الدالة: HCMV، مرضى الثلاسيميا، المتبرعين بالدم، ELISA، IL-6. 


\section{INTRODUCTION}

Human cytomegalovirus (HCMV) is the genetically most complex virus among all human pathogenic viruses and the largest representative of all herpesviruses (Karbach, 2012). HCMV or human herpesvirus 5 (HHV-5) is a prototypic member of the human Herpesviridae family, subfamily Betaherpesvirinae, ranging from about $20 \mathrm{~nm}$ to about $300 \mathrm{~nm}$ in diameter, is an enveloped double stranded DNA virus (Alston, 2017), with a genome of $236 \mathrm{kbp}$ and more than 170 open reading frames (ORFs) encoding functional proteins (Hage et al., 2017), the genome is packaged in an icosahedral capsid surrounded by a proteinaceous tegument layer or matrix, within a host-derived envelope decorated with viral glycoproteins (Bradley, 2008). HCMV is a common infectious agent which is well adapted to its host. Following primary infection, which is almost always asymptomatic in people with normal immunity and the virus establishes latency. The spreading of HCMV from person to person is by direct contact such as kissing, sexual contact and getting saliva or urine on your hands and then touching eyes, nose or mouth (Dupont and Reeves, 2016). The infection can occur through blood transfusion from donors with active or latent infection(Choobineh et al., 2009). HCMV can lead to morbid, complication or lethal consequences in various types of immunocompromised blood recipients, including thalassemic patients especially splenectomized persons and AIDS patients, therefore thalassemic patients could be at risk for the transfusion-related HCMV infection(Germenis and Politis, 1989). Thalassemias are a growing health problem worldwide (Vichinsky, 2016). It is inherited disorders of Hemoglobin ( $\mathrm{Hb}$ ) synthesis resulting from an alteration in the rate of globin chain production (Baker et al., 2013). HCMV is also the most common congenital and infantile viral infectious agent throughout the world (Mareri et al., 2016). HCMV infection induces many inflammatory cytokines including Interleukin -6 (IL-6) which is generated in response to nuclear factor kappa B (NF- $\kappa$ B) activation, function to activate natural killer (NK) cells which to limits replication and spread of the virus (Davey, 2011), which may contribute to the pathology of the infection (John et al., 1999). IL-6 is a typical example of such a multifunctional polypeptide cytokine (Taher, 2013). Diagnosis of active HCMV infection by ELISA for HCMV-specific IgM antibodies has been shown to be superior and practical. Detection of HCMV-specific IgG antibodies in blood is an indicator of previous exposure to HCMV while IgM antibodies are associated with active CMV infection (Njeru et al., 2008).

\section{MATERIALS AND METHODS}

Two hundred of thalassemic patients and 180 blood donor samples were included for detection HCMV. Five $\mathrm{ml}$ of blood was collected by vein puncture using $5 \mathrm{ml}$ disposable syringe from each subject enrolled in this study. Blood samples were placed in sterile test tube and left for 30 minutes at $37^{\circ} \mathrm{C}$ then were centrifuged at $3000 \mathrm{rpm}$ for 15 minutes then the serum samples were collected removed and the obtained sera were then aspirated using mechanical micropipette and

transferred into three Eppendorf tubes which labeled and then stored in deep freeze at $-20^{\circ} \mathrm{C}$ for late serological testing, by using ELISA technique for IgG and IgM of HCMV detection according to manufacturer's instructions [IgG, IgM IMMUNOLAB GmbH, Germany]

Serum IL-6 level was estimated using ELISA technique (KOMA BIOTECH, Korea).

\section{RESULTS}

Out of 200 thalassemic patient the HCMV-IgG seroprevalence by ELISA was detected in 152 (76.00 \%). The HCMV-IgM postitive antibodies was 14(7.00\%), so both HCMV-IgG and HCMVIgM seropositivity at the same time was $3(1.5 \%)$ as shown in the (Table 1$)$. In this study the seroprevalence of HCMV (IgM, IgG, and (IgM/IgG)) for the 180 blood donor, were detected in $7(3.88 \%), 67(37.77 \%)$, and $4(2.22 \%)$ ) respectively by ELISA technique as show in (Table 2). The highest rates of increasing serum IL-6 were detected in $57.89 \%, 71.42 \%$, and $66.67 \%$ in patients with HCMV-IgG, HCMV-IgM and both HCMV-IgG/IgM seropositve respectively as shown in (Table 3). Table (4) shows the serum IL6 Level among HCMV seropositive blood donors with 
HCMV antibodies type. The rates of increased serum IL-6 were detected in $30.88 \%, 51.15 \%$, and $50.0 \%$ in patients with HCMV-IgG, HCMV-IgM and both HCMV-IgG/IgM seropositve respectively.

Table 1: Seroprevalence of HCMV antibodies among thalassemic patients

\begin{tabular}{|c|c|c|}
\hline \multirow{2}{*}{$\begin{array}{c}\text { Seroprevalence } \\
\text { of HCMV antibodies }\end{array}$} & \multicolumn{2}{|c|}{ ELISA test result } \\
\cline { 2 - 3 } & No & $\%$ \\
\hline $\operatorname{IgM}(-)$ and $\operatorname{IgG}(+)$ & 152 & 76.00 \\
\hline $\operatorname{IgM}(+)$ and $\operatorname{IgG}(-)$ & 14 & 7.00 \\
\hline $\operatorname{IgM}(+)$ and $\operatorname{IgG}(+)$ & 3 & 1.5 \\
\hline $\operatorname{IgM}(-)$ and $\operatorname{IgG}(-)$ & 31 & 15.50 \\
\hline Total & 200 & 100 \\
\hline
\end{tabular}

Table 2: Seroprevalence of HCMV antibodies among blood donor

\begin{tabular}{|c|c|c|}
\hline \multirow{2}{*}{$\begin{array}{c}\text { Seroprevalence } \\
\text { of HCMV antibodies }\end{array}$} & \multicolumn{2}{|c|}{ ELISA test result } \\
\cline { 2 - 3 } & No & \% \\
\hline $\operatorname{IgM}(-)$ and $\operatorname{IgG}(+)$ & 68 & 37.77 \\
\hline $\operatorname{IgM}(+)$ and $\operatorname{IgG}(-)$ & 7 & 3.88 \\
\hline $\operatorname{IgM}(+)$ and $\operatorname{IgG}(+)$ & 4 & 2.22 \\
\hline $\operatorname{IgM}(-)$ and $\operatorname{IgG}(-)$ & 101 & 56.13 \\
\hline Total & 200 & 100 \\
\hline
\end{tabular}

Table 3: Serum IL6 Level Among HCMV seropositive in thalassemic patients

\begin{tabular}{|c|c|c|c|c|c|c|c|c|}
\hline \multirow{3}{*}{$\begin{array}{l}\text { HCMV Antibodies type } \\
\text { Seropositive }\end{array}$} & \multicolumn{8}{|c|}{ Serum IL6 Level } \\
\hline & \multicolumn{2}{|c|}{ Normal } & \multicolumn{2}{|c|}{ Increased } & \multicolumn{2}{|c|}{ Decreased } & \multicolumn{2}{|c|}{ Total } \\
\hline & No & $\%$ & No & $\%$ & No & $\%$ & No. & $\%$ \\
\hline HCMV- IgM (-) / IgG (+) & 60 & 39.47 & 88 & 57.89 & 4 & 2.63 & 152 & 100 \\
\hline HCMV- IgM (+) / IgG (-) & 4 & 28.57 & 10 & 71.42 & 0 & 0 & 14 & 100 \\
\hline HCMV- IgM $(+) / \operatorname{IgG}(+)$ & 1 & 33.33 & 2 & 66.67 & 0 & 0 & 3 & 100 \\
\hline Total & & & & & & & 169 & 100 \\
\hline
\end{tabular}

Table 4: Serum IL6 Level Among HCMV seropositive donor

\begin{tabular}{|c|c|c|c|c|c|c|c|c|}
\hline \multirow{3}{*}{$\begin{array}{c}\text { HCMV Antibodies type } \\
\text { Seropositive }\end{array}$} & \multicolumn{8}{|c|}{ Serum IL6 Level } \\
\hline & \multicolumn{2}{|c|}{ Normal } & \multicolumn{2}{|c|}{ Increased } & \multicolumn{2}{|c|}{ Decreased } & \multicolumn{2}{|c|}{ Total } \\
\hline & No & $\%$ & No & $\%$ & No. & $\%$ & No & $\%$ \\
\hline HCMV- IgM (-) / IgG (+) & 46 & 67.65 & 21 & 30.88 & 1 & 1.47 & 68 & 100 \\
\hline HCMV- $\operatorname{IgM}(+) / \operatorname{IgG}(-)$ & 3 & 42.85 & 4 & 57.15 & 0 & 0 & 7 & 100 \\
\hline HCMV- IgM (+) / IgG (+) & 2 & 50.00 & 2 & 50.00 & 0 & 0 & 4 & 100 \\
\hline Total & & & & & & & 79 & 100 \\
\hline
\end{tabular}

\section{DISCUSSION}

HCMV is a global prevalence infection and considered as basic health problem in various societies, several studies have been conducted around the world (Safabakhsh et al., 2014). Cytomegalovirus is a common infectious agent which is well adapted to its host. Following primary 
infection, which is almost always asymptomatic in people with normal immunity and the virus establishes latency (Dupont and Reeves, 2016). The HCMV infection induces both an innate immune response as well as an adaptive immune response, which control primary HCMV and/or recurrent infections (Taher, 2013). HCMV infection causes an immunosuppressive effect by inhibiting T cells (La Rosa and Diamond, 2012). HCMV can lead to morbid, complication or lethal consequences in various types of immunocompeomised blood recipients, including thalassemic patients. Immunological abnormalities in thalassemia are caused by either the illness, or therapy methods (ChD, 2014).

In the present study the rate of HCMV-IgG seroprevalence were tested among the total 200 thalassemic patients was detect in $76.00 \%$, while another studies reported in Iran this infection was 100\% (Aghaeipour et al., 2005) and 95.9\% (Moghimi et al., 2015), while in Athens, Greece it was reported in 89.6\% (Germenis and Politis, 1989). The rate of HCMV-IgM seropositive in current study was $7 \%$ that's higher than the rate reported by some studies among thalassemic patient were in Iran reported 5.2\% (Moghimi et al., 2015), while lower than that reported in Najaf which was $28.6 \%$ ( Saif et al., 2013). The present study showed the rate of seropositive for both HCMV-IgM and HCMV-IgG was $1.5 \%$.

Regarding the seroprevelence of HCMV antibodies among blood donors; the rate of HCMVIgG was 37.77\% that's more lower than in other studies in Najaf it was reported $46.6 \%$ (Yasir and Majhol, 2008), While it was reported at $97.4 \%$ in France (Gargouri et al., 2000). The rate of HCMV-IgM in our study was reported at $3.88 \%$ compared with other studies which showed higher than our results, in Mosul it was reported to be 11.11\% (Al-Dabbagh, 2011), in Kashan, the prevalence of CMV-IgM was reported as $2.3 \%$ (Moniri et al., 2004).

In the present study the highest rates of serum IL-6 57.89\%, $71.42 \%$, and $66.67 \%$ were seen within HCMV-IgG, HCMV-IgM and both HCMV-IgG/IgM seropositive respectively. The level serum IL-6 among HCMV seropositive blood donors in the present study of increased serum IL-6 $30.88 \%, 57.15 \%$, and $50.0 \%$ were seen in HCMV-IgG, HCMV-IgM and both HCMV-IgG/IgM seropositve respectively. Other studies in Turky agreed with our result which mention that the IL-6 determined by ELISA patients with beta- thalassemia were found plasma IL-6 concentrations increased compared with control (Oztürk et al., 2001). In Osijek, Croatia mention that patients with Inflammatory Bowel Disease, the concentrations of IL-6 were significantly higher when compared to healthy blood donors (Takač et al., 2014). CMV infection increased both IL-6 protein and that the CMV immediately 1 gene product increased expression of the IL-6 promoter. It has been proposed that the subsequent interaction between virus and inflammatory cytokines (Geist and Lucia, 1996). While decreased the levels of IL-6 in few case of CMV infected patients may due to other cause as body weight loss affected the reduction of levels of IL-6, a pro- inflammatory factor, and the loss of adipose tissue caused by the reduction of body weight, Body Mass Index (BMI) and body fat percentage affected the gene expression and the consequent production of circulating in flammatory (Christiansen et al., 2010; Oberbach et al., 2008).

The different rates of HCMV antibodies seroprevalence recorded by this and others studies may be due to hygienic conditions, communal life style, and cultural factors (Staar and Israa, 2012; Arabpour, 2007) from one country to others and among different areas, in addition to the different techniques used in the diagnosis that may differ in their sensitivity and specificity in HCMV diagnosis. In comparison the spreading of HCMV specific antibodies between thalassemic patients and blood donors the present study showed the difference in rates of HCMV antibodies so the rate of HCMV-IgG and HCMV-IgM antibodies were higher among thalassemic patients than that founds among blood donor, while the rate of seropostive for both HCMV-IgG/IgM was higher among blood donors, this finding may be due to the effect of blood transfusion to increase the rates of HCMV infection in thalassemic patients (Ziemann and Hennig, 2014), while the highest rate of 
both HCMV-IgG/IgM among blood donors this may due to age, close contact, parity and sexual maturity as the most probable associated factors.

Quit hookah and smoking, especially people who have polycythemia and prevent cupping and blood donation in irregular places in addition to avoidance of tattoo that consider as main causes of increasing HCMV infection in community.

\section{REFERENCES}

Al-Dabbagh, K.A. (2011). Detection of toxoplasma gondii $\operatorname{IgM}$ and cytomegalovirus $\operatorname{IgM}$ antibodies among blood donors in Mosul. Iraqi J. Pharmacy, 11(2), 85-92.

Alston, C.I. (2017). "Suppressor of Cytokine Signaling (SOCS) 1 and SOCS3 Stimulation During Experimental Cytomegalovirus Retinitis: Virologic, Immunologic, or Pathologic Mechanisms". Dissertation, Georgia State University. Georgia.

Arabpour, M.; Kaviyanee, K.; Jankhah, A.; Yaghobi, R. (2007). Human cytomegalovirus infection in women of childbearing age throughout Fars Province-Iran: a population-based cohort study. Malaysian J. Microbiology, 3(2), 23-28.

Baker, N.; Alnakashabandi, A.; Alsaqy, A.H.; Alrabaty, A. (2013). Growth Pattern and Sexual Maturation Rate in $\beta$-Thalassemia Major Patients from Thalassemia Center Erbil. Iraqi Academic Scientific J., 12(1), 40-44.

Bradley, A.J. (2008). Analysis of two hypervariable human cytomegalovirus genes, UL146 and UL139. Doctoral dissertation, University of Glasgow. Scotland.

ChD, A. (2014). Immunologic abnormalities in $\beta$-thalassemia. J. Blood Disorders Transfusion, 5(224), 2.

Choobineh, H.; Alizadeh, S.H.; Yazdi, M.S.; Vaezzadeh, F.; Dargahi, H.; Pourfatholah, A.A. (2009). Serological evaluation of major beta thalassemia patients below15 for cytomegalovirus infection in Iran. Research J. Biol. Sci., 2, 584-9.

Christiansen, T.; Paulsen, S.K.; Bruun, J.M.; Pedersen, S.B.; Richelsen, B. (2010). Exercise training versus diet-induced weight-loss on metabolic risk factors and inflammatory markers in obese subjects: a 12-week randomized intervention study. American J. Physiol. Endocrinol. and Metabolism, 298(4), E824-E831.

Davey, A.S. (2011). The Placenta as a Viral Reservoir: Implications for Congenital Cytomegalovirus Infection. Msc Thesis, University of Alberta.Canada.

Dupont, L.; Reeves, M.B. (2016). Cytomegalovirus latency and reactivation: recent insights into an age old problem. Reviews in Medical Virology, 26(2), 75-89.

Gargouri, J.; Elleuch, H.; Karray, H.; Rekik, H.; Hammami, A. (2000). Prevalence of anti-CMV antibodies in blood donors in the Sfax region (value in blood transfusion). La Tunisie Médicale, 78(8-9), 512-517.

Geist, L.J.; Lucia, Y.D. (1996). Cytomegalovirus modulates interleukin-6 gene expression1. Transplantation, 62(5), 653-658.

Germenis, A.; Politis, C. (1989). Thalassemic patients are at high risk for transfusion-transmitted cytomegalovirus infections. Acta Haematologica, 82(2), 57-60.

Hage, E.; Wilkie, G.S.; Linnenweber-Held, S.; Dhingra, A.; Suárez, N.M.; Schmidt, J.J.; Schulz, T.F. (2017). Characterization of human cytomegalovirus genome diversity in immunocompromised hosts by whole-genome sequencing directly from clinical specimens. The J. Infectious Diseases, 215(11), 1673-1683.

John, C.F.; Edelman, L.; Bennion, D.W.; Anderson, J.L. (1999). Cytomegalovirus induction of interleukin-6 in lung fibroblasts occurs independently of active infection and involves a $\mathrm{G}$

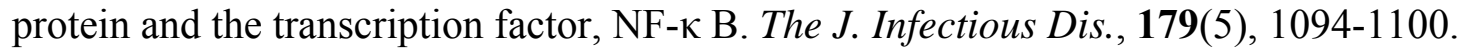

Karbach, A. (2012). "Protection from Cytomegalovirus Infection by Glycoprotein-specific Monoclonal Antibodies". Dissertation, Erlangen, Universität Erlangen-Nürnberg. 
La Rosa, C.; Diamond, D.J. (2012). The immune response to human CMV. Future Virol., 7(3), 279293.

Mareri, A.; Lasorella, S.; Iapadre, G.; Maresca, M.; Tambucci, R.; Nigro, G. (2016). Anti-viral therapy for congenital cytomegalovirus infection: pharmacokinetics, efficacy and side effects. The J. Maternal-Fetal and Neonatal Medicine, 29(10), 1657-1664.

Moghimi, M.; Doosti, M.; Vahedian-Ardakani, H.A.; Talebi, A.; Akhavan-Ghalibaf, M.; Najafi, A.; Khodayari, F. (2015). Serological Study on Cytomegalovirus and Toxoplasma Gondii in Thalassemia Major Patients of Yazd, Iran. Iranian J. Pediatric Hematol. and Oncol., 5(3), 149.

Moniri, R.; Mosayebii, Z.; Mossavi, G.A. (2004). Seroprevalence of cytomegalovirus, hepatitis B, hepatitis $\mathrm{C}$ and human immunodeficiency virus antibodies among volunteer blood donors. Iranian J. Public Health, 33(4), 38-42.

Njeru, D.G.; Mwanda, W.O.; Kitonyi, G.W.; Njagi, E.C. (2009). Prevalence of cytomegalovirus antibodies in blood donars at the National Blood Transfusion Centre, Nairobi. East African Medical J., 86(12), 58-61.

Oberbach, A.; Lehmann, S.; Kirsch, K.; Krist, J.; Sonnabend, M.; Linke, A.; Kovacs, P. (2008). Long-term exercise training decreases interleukin-6 (IL-6) serum levels in subjects with impaired glucose tolerance: effect of the- $174 \mathrm{G} / \mathrm{C}$ variant in IL-6 gene. European $\mathrm{J}$. Endocrinology, 159(2), 129-136.

Öztürk, O.; Yaylim, İ.; Aydin, M.; Yilmaz, H.; Agaçhan, B.; Demiralp, E.; İsbir, T. (2001). Increased plasma levels of interleukin-6 and interleukin-8 in $\beta$-thalassaemia major. Haematologia, 31(3), 237-244.

Safabakhsh, H.; Karimi, G.; Tehranian, F.; Tehranian, B. (2014). Demography and seroprevalence of cytomegalovirus infection in blood donors in Mashhad in 2009. J. American Sci., 10(2), 139-142.

Saif, J.; Heider, H., Abbas, N., Alwan, H. (2013). Incidence of HCMV in thalassemic patients in AL-Najaf governorate. Medical J. Babylon University, 21(2), 643-650

Staar, M.; Israa, H. (2012). Cytomegalovirus in pregnancy Second Scientific Conference - Science College - Tikrit University, Iraq (2012), 130-133.

Taher, C. (2013). The role of human cytomegalovirus infection in cancer. MD Thesis, Institute for medicin, Solna/Dept of Medicine, Solna. Stockholm, Sweden.

Takač, B.; Mihaljević, S.; Štefanić, M.; Glavaš-Obrovac, L.; Kibel, A.; Samardžija, M. (2014). Importance of interleukin 6 in pathogenesis of inflammatory bowel disease. Collegium Antropologicum, 38(2), 659-664.

Vichinsky, E. (2016). Non-transfusion-dependent thalassemia and thalassemia intermedia: epidemiology, complications, and management. Current Medical Research and Opinion, 32(1), 191-204.

Yasir, S.J.; Majhol, R.B. (2008). Screening of anti-cytomegalovirus IgG antibodies in blood donors in Al-Najaf Governorate. Kufa Medical J., 11(2), 271-276.

Ziemann, M.; Hennig, H. (2014). Prevention of transfusion-transmitted cytomegalovirus infections: which is the optimal strategy?. Transfusion Medicine and Hemotherapy, 41(1), 40-44. 